\title{
JUURNAL_RU
}

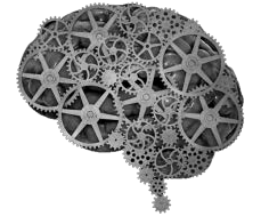

COMPANY GROUP "INTELLEKT"

\author{
Костерева Л.И. \\ МГПУ \\ Москва, Россия
}

doi: 10.18411/lj2016-3-60

\section{Актуальные проблемы взаимодействия старшеклассников, обучающихся на дому}

На современном этапе развития общества, в условиях социальноэкономической нестабильности и бурных процессов интеграции, к личности предъявляются высокие требования. Однако не каждый человек может адаптироваться к стремительно меняющимся условиям среды.

Одной из актуальных проблем нашего общества является изучение личности старшеклассников, их проблем взаимодействия. Исследование их психологических особенностей, необходимо для последующего интегрирования их в социум, создание определенных условий, способствующих развитию адаптивных качеств личности, и особенно у старшеклассников, которые обучаются на дому.

Взаимодействие является одной из важнейших сфер жизнедеятельности старшеклассника. Значение процесса взаимодействия в формировании основных компонентов личности в юношеском возрасте велико. От того, как будет складываться взаимодействие, зависит формирование будущей личности. Поэтому наше исследование о проблемах взаимодействия в старшем школьном возрасте является актуальной темой для изучения.

Многие исследователи (Л.С. Выготский, Л.И. Божович, И.С. Кон) считают, что огромное значение имеет для старших школьников взаимодействие со сверстниками. Взаимоотношение со сверстниками находится 
в центре жизни старшеклассника, и во многом определяет все остальные стороны его поведения и деятельности.

По мнению А.Я. Варги, Д.И. Фельдштейна, Э.Г. Эйдемиллера, семья формирует систему паттернов поведения у личности в общении и оказывает влияние на взаимодействие со сверстниками, которые являются наиболее приоритетными в этом возрасте.

Особое значение взаимодействие приобретает в образовательном процессе, который представляет единство обучения и воспитания. Основной задачей образовательного процесса есть формирование личности в процессе обучения. Но образовательный процесс только тогда будет выступать условием формирования личности, когда педагоги и учащиеся будут его активными субъектами.

T.А. Шилова приводит слова о том, что «перед работниками образовательных учреждений стоит задача разработки эффективных моделей образовательного процесса».

Согласно Л.Р. Аркатовой, одним из вариантов индивидуального обучения выступает надомное обучение, положительными сторонами которого являются индивидуальный план и темп обучения, которые дают учащемуся выполнять учебные задания, индивидуальные нагрузки и легко распределять их не только в течение дня, но и в течение всей недели. Индивидуальная работа позволяет учесть темп работы учащегося, и работоспособность, и утомляемость и другие особенности.

В последние годы проблема надомного обучения привлекает все большее внимание специалистов (С.В. Трошина, Л.В. Пасечник, А.Н. Ганичева, О.Л. Зверева, Н.В. Флит, Е.В. Савушкина, Т.В. Тихоненко и др.), которые в своих работах пытаются выделить и структурировать опыт учителей обучения на дому.

Учитель надомного обучения часто сталкивается со многими трудностями, решение которых требует определенных психологических 
знаний, специфических коррекционно-развивающих умений, а также создания особой системы межличностных отношений в системе учитель - ученик родитель.

Педагогическими условиями эффективности системы индивидуальной работы учителя с обучающимися надомного обучения, считает Л.Р. Аркатова, являются: разработка и реализация модели индивидуальной работы; использование знаний об особенностях учащихся-надомников, индивидуальной восприимчивости обучаемого к тому или иному способу подачи информации, к методам обучения на каждом этапе познания.

Как отмечают учёные А.И. Дьячков, А.П. Гозова, А.В. Гущина, С.А. Зыков, М.И. Никитина, учащиеся, не имеющие достаточного социального опыта, сталкиваются с трудностями социальной адаптации и дальнейшей интеграции в общество.

В своём исследовании О.С. Рыжова отмечает у учащихся, обучающихся на дому, узкий кругозор, интеллектуальную пассивность, низкий уровень развития психических процессов, познавательных навыков, отсутствие интереса к учебной деятельности, социальную и школьную дезадаптацию.

Также О.С. Рыжова отмечает личностные нарушения, которые проявляются в незрелости эмоционально-волевой сферы, эгоцентризме, повышенной внушаемости, инертности, преобладании внешней мотивации, заниженная самооценка и искажённый уровень притязаний. Так же, отмечает автор, имеются нарушения в межличностных отношениях - как следствие частичной изоляции от общества (незнание или игнорирование некоторых социальных требований и норм).

Согласно статистике в последние годы отмечается увеличение количества детей, обучающихся на дому. Можно предположить, что частая и длительная отстраненность учащихся из школьного коллектива может негативно отразиться на их личностном формировании, нарушении основных механизмов 
взаимодействия с социумом и способствовать возникновению трудностей в построении межличностных отношений.

Цель данного исследования - изучить актуальные проблемы взаимодействия старшеклассников, обучающихся на дому

\section{Условия и методы исследования}

Исследование проводилось на базе Федерального государственного бюджетного учреждения "Федеральное бюро медико - социальной экспертизы" Министерства труда и социальной защиты Российской Федерации. В исследовании приняли участие 60 старшеклассников, в возрасте 15 - 16 лет г. Москвы: 30 учащихся, обучающиеся в общеобразовательной школе, 30 человек испытуемые, обучающиеся на дому.

Для проведения нашего исследования, были использованы следующие методики: методика «Оценка уровня общительности» (В.Ф. Ряховский); методика диагностики коммуникативной установки В. В. Бойко; методика исследования самоотношений В.В. Столина, С.Р. Пантелеева.

Расчет основных количественных показателей методики исследования самоотношений В.В. Столина, С.Р. Пантелеева показывает выраженные различия в личности старшеклассников. Среди учеников посещавших общеобразовательную школу, высокую самоуверенность показали 56\%, 40\% высокую самоценность, по остальным шкалам: саморуководство, отраженное самоотношение, самопринятие, самопривязанность, внутренний конфликт, самообвинение - средние значения. Среди испытуемых, обучающихся на дому у 77\% испытуемых преобладает высокая замкнутость, у 53\% старшеклассников, обучающихся на дому, преобладает низкая самоценность, 44\% отметили низкое самопринятие, 67\% указали на высокий внутренний конфликт, 47\% отметили высокое самообвинение.

Для оценки уровня общительности, мы применили методику «Оценка уровня общительности» (В.Ф. Ряховский), которая позволяет определить уровень общительности, коммуникабельности личности. Анализ полученных 
результатов свидетельствует о том, что 47\% школьников показали нормальную коммуникабельность, любознательность, достаточно терпеливы в общении с другими, отстаивают свою точку зрения без вспыльчивости. 33 \% обучающихся имеют средний уровень, охотно знакомятся с новыми сверстниками, любят бывать в центре внимания, могут вспылить, но быстро отходят. 20\% учащихся показали низкий уровень общительности. Старшеклассники, обучающиеся на дому, в большинстве имеют уровень общительности ниже среднего- 43\%, испытуемые с уровнем общения ниже среднего общительны в определенной мере, не пугаются новых проблем, однако с новыми людьми сходятся с оглядкой; в спорах и диспутах участвуют неохотно. Испытуемые с низким уровнем общительности - 47\%, замкнуты, неразговорчивы, имеют мало друзей. Новая ситуация и обстановка могут вывести их из равновесия. $10 \%$ старшеклассников, обучающихся на дому, показали нормальную коммуникабельность.

Методика диагностики коммуникативной установки В. В. Бойко предназначенная для выявления негативных коммуникативных видов установок личности по отношению к другим людям показала следующие результаты: что среди старшеклассников, посещавших общеобразовательную школу, имеют выраженную негативную коммуникативную установку - 66\% учащихся, 23\% отмечают завуалированную жестокость в отношениях к людям, в суждениях о них, 33\% - показывают открытую жестокость в отношениях к людям. Среди испытуемых, обучающихся на дому, $83 \%$ старшеклассников имеют выраженную негативную коммуникативную установку, 37\% - отмечают завуалированную жестокость в отношениях к людям, 23\% - показывают открытую жестокость в отношениях, 17\% старшеклассников, обучающихся на дому, выделили негативный личный опыт общения с окружающими.

Таким образом, важным результатом нашего исследования являются выраженные различия проблем взаимодействия старшеклассников, обучающихся в общеобразовательной школе и на дому. Старшеклассники, 
обучающиеся на дому, характеризуются некоторыми личностными особенностями, которые затрудняют межличностное взаимодействие.

Создание благоприятных психологических условий для саморазвития личности, для формирования психологической готовности к жизненному самоопределению, успешному взаимодействию, к проявлению творческой активности, к дружбе и сотрудничеству возможно при совместной работе старшеклассников с педагогами и психологами. Перспективой дальнейшего изучения проблемы может стать разработка программы психологической коррекции эффективного взаимодействия старшеклассников, обучающихся на дому. 


\section{Литература:}

1. Рыжова О.С. Сущность и специфика социально-педагогических технологий работы с детьми с ограниченными возможностями здоровья // Мир науки. 2014. № 4. С. 44.

2. Шилова Т.А. Профилактика алкогольной и наркотической зависимости у подростков в школе: Практическое пособие. - М. Айрис-пресс, 2005.- 96с.

3. Шилова Т.А. Диагностика психолого - социальной дезадаптации детей и подростков. Практическое пособие. - М. Айрис-пресс, 2006.-112c.

4. Шилова Т.А. Состояние проблемы неравномерности и гетерохронности и ее роль в психическом развитии в онтогенезе/ Т.А. Шилова // Системная психология и социология №3 (I) 2011, C 67-77.

5. Шилова Т.А., Костерева Л.И. Психологические особенности направленности личности старшеклассников, обучающихся на дому// Вестник РУДН. - Серия: Психология и педагогика. 2015. №2. С.98-102. 